\title{
The Color Palette in the Work of the Iranian Writer Raziye Tujjar
}

\author{
Oydin Turdiyeva \\ Lecturer, International Islamic Academy of Uzbekistan, Uzbekistan
}

http://dx.doi.org/10.18415/ijmmu.v8i8.2973

\begin{abstract}
The article analyzes the symbolic expressions reflected in colors in the stories of Razia Tujjar, one of the greatest representatives of modern Iranian literature. In modern Iranian literature, the famous writer Raziye Tujjar has a great ability to fully understand a woman's heart, reach the depths of a woman's heart, revealing all its secrets. Raziye Tujjar writes in a unique style that distinguishes her works from other writers for the richness of philosophical observations, the beauty of language and style, and the presentation of social problems. Most of the characters in her stories are women. The writer is very fond of colors in her stories. She sees the world through different colors and shades. Especially gray, full of hardships, she describes it and ends her work in a depressed state. Our scientific article also emphasizes the role of color symbolism in the richness of the literary imagery of the writer.
\end{abstract}

Keywords: Raziye Tujjar; Iran; Short Story; Color Palette; Female Heart; Explosion of Female Silence; Depressio; Expression of Colors

\section{Introduction}

Since ancient times, writers have used different colors to convey moods, emotions, hidden symbolic meanings. Color is one of the artistic expressions of a person's ability to perceive reality in literature. Color is life. The colorless world seems artificial to us. As fire produces light, light creates color. Color is a symbol of human emotions.

A new generation of women writers was appeared in literature, and women's creativity and the image of women began to be interpreted in a new way after the Islamic revolution. Talented writers such as Manije Jankoli, Samira Aslonpur, Zahra Zavoriyon, Vajihe Ali Akbari Somoni, Roziya Tujjor, who started their creative work after the 80s of the XX century, continued the tradition of women writers who started their creative work before the Islamic Revolution. Modern Iranian writers began to apply new styles, new content, and new forms in their works. The subject of their stories was a simple event in everyday life, the ordinary life of a person and the purpose of which was to penetrate deeper into the heart of the protagonist, to express her feelings more deeply. The situation occurred as a real literary phenomenon, although it contradicted the perceptions and notions formed about the status of women in Islamic society.

In modern Iranian literature, a woman cannot be compared to the well-known writer Rozia Tujjar in the full understanding of her heart, in reaching the depths of her heart, in discovering all its secrets. Colors play an important role in the stories of Rozia Tujjar, who has a place in modern Iranian prose. This helps the writer to convey the emotional experiences of the protagonists of the work. There are dozens of colors in the color spectrum of the stories of the writer, some of which we will discuss in this article.

\section{Materials and Methods}

Rozia Tujjar is one of the greatest representatives of modern Iranian literature. Rozia Tujjar was born in 1947 in Tehran. Her childhood was spent in one of the neighborhoods of Tehran. After graduating from high school, she studied psychology at the university. She began her writing career in 1985. 
Basically, a collection of several stories by a writer in the story genre has been known to the world. The

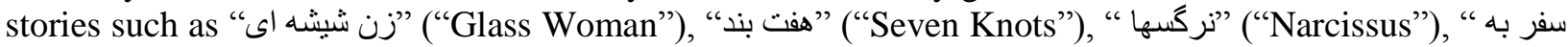

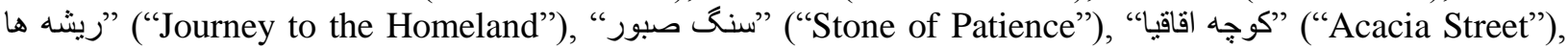
" "شعله و شب" "'Good Night”), ("The Dawn and the Night”) were translated into Russian, Urdu, Uzbek and other foreign languages.

Rozia Tujjor writes in a unique style that distinguishes her work from other writers in terms of its richness of philosophical observations, the beauty of language and style, and the presentation of social problems. Most of the protagonists of Rozia Tujjor's stories are women. For example, a mother who is still waiting for her missing son to return from the war, a bride who has not given up hope for her husband to return from the war, a woman who is suffering from her husband's indifference, and so on. This means that she is aware of the plight of women who face family, socio-economic, and moral problems.

The women who are the protagonists of her works do not try to escape or get rid of the conditions. Those heroes are entangled in complex circumstances, destiny, time, environment affect their lives and leave a mark on their lives. Writer sees a gray, world full of hardships, describes it, and completes her work in a depressing spirit. There is another feature that is unique to her work.

We see the wisdom of Iranian poets and writers Jalal Ole-Ahmad, Ahmad Shamlu's melodic, musical style of prose, Mehdi Ahavan's sadness and depression, Farooq Farrukhzad's "Iranian woman's state of silence, the explosion of women's silence in her works." [Muhammadrizo Ruzbeh, 2012]. Also, the expression of colors is reflected, and colors carry an important semantic load. It tries to create a complete picture of looking at an object with an artistic look through colors.

The title of the author's story “"ريزش زردها رويش سبز ها" ("The shedding of yellows, the growth of greens") from the author's collection "Both the apple and the star" prepares the reader to pay special attention to colors. Here, "yellow" and "green" colors in the story have their own symbolism. First of all, it should be noted that in each nation there is a symbolism of colors. Since this story focuses on yellow and green, we will focus on the meanings of these colors in different nations.

In many nations, the color yellow signifies negative meanings, such as sin, betrayal, sadness, decay, despair, illness. In addition, the "Yellow Jack" - a flag raised on ships as a sign of quarantine. In medieval Spain, heretics who were burned at the stake were also dressed in yellow. In China, yellow was the symbol of the Mediterranean. Yellow robes could only be worn by the emperor and her family. Special guests were also invited to the room with the yellow carpet.

From the title of the author's story " ريزش زردها رويش سبز ها" (Falling of yellows, the growth of greens") from the author's collection "Both the apple and the star" prepares the reader to pay special attention to colors. Here, the "yellow" and "green" colors in the story have their own symbolism. First of all, it should be noted that in each nation there is a symbolism of colors. Since the story focuses on yellow and green, we will focus on the meanings of these colors in different nations. In many nations, the color yellow signifies negative meanings, such as sin, betrayal, sadness, decay, despair, illness.

In addition, the "Yellow Jack" - a flag raised on ships as a sign of quarantine. In medieval Spain, heretics who were burned at the stake were also dressed in yellow. In China, yellow was the symbol of the Mediterranean. Yellow robes could only be worn by the emperor and her family. Special guests were also invited to the room with the yellow carpet.

Green is the color of life. Green has a positive quality and means such things as growth, rebirth of nature, hope, and youth. In Islam, the color green is a symbol of life; the symbol of Islam as well as the concept of paradise is associated with the color green. In the hadiths, it is propagated in green clothes. The story of Rozia Tujjor is about a doctor who treats patients. A woman who is accustomed to treating patients finds out that she is suffering from a dangerous disease and first suffers from a mental crisis. The story was written in a surrealistic style. The state of the protagonist is expressed through live sensations instead of explicit analysis. External coldness contradicts internal suffering. The doctor sighs, everything seems yellow to her: Yellow is a symbol of disease, yellow flowers, and yellow leaves. She sees the image of the patient in her own eyes, talks about the disease in her body, addresses the disease: 


$$
\begin{aligned}
& \text { خيال مه كنى كه هستى كه اين طور آمده ایى و در من جا كرفته اى؟ من مى تو انم همان طور كه آن هار ا با دادن جند قرص شفا مىدهم. } \\
& \text { خودم را هم. } \\
& \text { خيال ميكنى كه هستى اينطور آمده ایى و سر راهم نشسته اى ؟ ازدستت خلاص خو اهم شد. خواهى ديد. خلاص. خلاص }
\end{aligned}
$$

"Do you think that you exist? Do you think that you will just come and capture me? I will be able to cure myself as I treat them with a medicine.

"Do you think that you exist? Do you want to say that you have just come and stayed on my way? You will see that I will get rid of you. Get rid of you. Get rid of you..."

The story focuses a lot on psychological situations. The protagonist always feels like she is walking in a dream, half asleep. Then she pulls out the yellow flowers, losing everything that is yellow. Yellow things are being replaced by green grass. She falls into the river, stays in the rain, calms down a lot, and sparks of hope appear in her heart again. The protagonist's descent from the window into the river, her walk on the surface of the water, and her return to the place through the window are in fact processes in her psyche. The writer used unusual, fantastic elements, allowing freedom of imagination.

If you look closely, there is no plot at all. The doctor has no choice but to leave the room through the window, fall into the river, and return to work. In the story, the protagonist's inner thoughts, the flow of consciousness, her struggle with herself and her illness, her thoughts and associations (imaginations) are exchanged randomly with each other. Waiting for the village doctor to receive the patients, their number exceeded 250. The writer used many metaphors, figurative meanings, and the art of metaphor to describe patients waiting in line. For example: The swelled and reddened eyelids, the swelled and huge stomachs, the crippled and crying bodies [Muhammadrizo Ruzbeh: 2012].

The female doctor treats the patients; she fights for survival, for life. The symbolic meaning of the title of the story also means high spirits, i.e. "Falling of the yellows, the growth of the greens". Everything in yellow disappears and is replaced by greenery, which is a symbol of life.

The author's story "قاب انتظار” (Rescue) is also written in a realistic direction. The story is written in the form of a diary of the wife of a soldier who died in the 1980-1989 Iran-Iraq war, in the form of an appeal to a second person, the young bride's husband. The life of the Iranians is clearly expressed. Waiting for the holiday of Navruz, the food, customs, rituals, clothes, the bride's respect for her motherin-law, which is prepared on the holiday: (امروز با اصرار مو هاى بنبه الى مادرت را حنا بستم و ناخن باهايش را كرفنت. -"I dyed mother's grey hair and removed her toenails". The fortune-telling on Hafiz's Devon and other Iranian characteristics are described in simple, fluent language. The story with these aspects is very interesting. In her story, the author pays a lot of attention to colors, in particular, about the inadequacy of the color yellow. زردى مان را به آتش مى داديم و سرخى اش را مى كرفتيم -As in the story above, yellow has a negative color and red has a positive color. Red usually means blood and fire. The meanings of the color are very different and in some cases contradictory. Red sometimes signifies joy, beauty, love, and a full life, and in some cases negative meanings such as enmity, revenge, war. But in the story of "Rescue," which we are analyzing, red is used in a positive sense.

Along with realistic stories, the writer is also the author of modernist-oriented stories characterized by surrealistic landscapes. She is both a realist and a surrealist writer. As a surrealist writer, آن صداى " writer describes the mental experiences and inner states of the heroes more. Roziya Tujjar's story " "روشن" ("That unquenchable voice") The short story "That Unquenchable Voice" is distinguished from realistic short stories by the abundance of signs, dreams, predictions, dreams interpretation, symbols and some mysterious voices.

In her story, the writer paid a lot of attention to colors and played with colors as well. The writer finds and uses unique analogies in the creation of colors in the story:

$$
\begin{aligned}
& \text { hundreds of red, yellow and blue stars } \\
& \text { white and ash-gray mountain } \\
& \text {-key of goldish color }
\end{aligned}
$$


-wings of coppered color

the leaves were red, yellow and orange

- the darkened sky

- باغنه سرخ و نه زردو نه نارنجى a garden that is neither red, nor yellow, nor orange

The red, yellow and orange of the leaves or the darkness of the sky are simple expressions, but the red, yellow and blue stars of the stars are the original analogy.

As we have witnessed, the writer is well aware of the ups and downs of life, conveys it to the reader in the expression of different colors from the scenes of life. The images and colors that Roziya Tujjor chose for the image stood out with their brightness and originality. The world of women, the destiny of women, and the image of women shone in different colors in her works.

\section{Conclusion}

It can be concluded that in modern Iranian literature, the work of the well-known writer Rozia Tujjor stood out in the full understanding of the woman's heart, in reaching the depths of her heart, in discovering all its secrets. A new interpretation of the image of a woman is observed in her stories, the image of a woman who is intelligent, has her own voice and will, rather than the traditional oppressed eastern woman. Roziya Tujjor uses a poetic style in her stories. One of the hallmarks of her stories is the predominance of a sad mood. The writer often refers to colors, especially when describing mood. The stories of Tujjor are not rich in events, but these stories are a narration of a journey into the inner world of man, especially women.

\section{References}

Imomova G. Ruhiy iztiroblar. [Mental anguish], Tashkent, 1992.

Jamol Mirsodeqi. Adabiyyote dostoni. [Fiction] Tehran, 1997.

Mohammad Hoquqi. Moruri bar torixe adab va adabiyyote emruze Iron. [A Review of the Hertory and Contemporary of Iranian Literature. Tehran, 1998.

Muhammad Qosemzodeh, Dostonnevisone moasere Iron [Contemporary Iranian writers] Tehran, 2004.

Muhammadrizo Ruzbeh. Hozirgi zamon Eron adabiyoti [Modern Iranian literature]. Tashkent, 2012.

Roziye Tujjor. Ham sib, ham setore. [Both the apple and the star]. Tehran, 2007.

Sovremennaya iranskaya proza. Antologiya iranskogo rasskaza. Contemporary Iranian prose. [Anthology of Iranian Story]. Tom I, II. Saint-Petersburg, 2010.

www.hawzah.net/fa/Magazine/View/3992/.../24456

http://www.sarshar.org/archives/critics/post_836.html

\section{Copyrights}

Copyright for this article is retained by the author(s), with first publication rights granted to the journal.

This is an open-access article distributed under the terms and conditions of the Creative Commons Attribution license (http://creativecommons.org/licenses/by/4.0/). 